\title{
Intercomparison of subglacial sediment-deformation models: application to the Late Weichselian western Barents margin
}

\author{
Daniel Howell, ${ }^{1}$ Martin J. Siegert ${ }^{2}$ \\ ${ }^{1}$ Centre for Glaciology, Institute of Geography and Earth Sciences, University of Wales, Aberystwyth Sr23 3DB, Wales \\ ${ }^{2}$ Bristol Glaciology Centre, School of Geographical Sciences, University of Bristol, Bristol BSo 1SS, England
}

\begin{abstract}
Numerical experiments, where a simple ice-sheet model was coupled with sediment-deformation models, were performed to investigate the transport of glacigenic material to the western Barents Shelf during the Late Weichselian. The ice-sheet model, and its environmental inputs, has been matched previously with a series of geological datasets relating to the maximum extent of the ice sheet (Howell and others, http://www.ggg.qub.ac.uk [rp05/1999]). Additional geological data on the volumes of sediment delivered to the Bear Island fan (Barents continental margin) are available for comparison. The experiments indicate the sensitivity of sediment transport and deposition to variations in (a) the ice-stream model and (b) a variety of model parameters. Two ice-stream models were used: (1) a heightabove-buoyancy model, in which basal velocity is controlled by basal driving stress and a buoyancy-induced reduction in the normal load beneath a marine-based ice sheet; and (2) a modified version of the method presented by Alley (1990) in which basal velocity is related to pore-water pressure, sediment thickness, and driving basal stress. The results of the two different models were then compared. An extensive set of sensitivity tests was carried out to determine sediment-transport response to changes in the model's parameters. Results indicate that, using physically realistic parameters for deforming subglacial sediment, both models reproduce the volume of Late Weichselian sediment measured on the Bear Island fan. Results from both models are sensitive to (1) cohesion of the sediment and (2) the thickness of deforming sediment beneath the ice sheet. The two models exhibited different degrees of sensitivity to the sediment parameters, with the height-above-buoyancy model proving to be less sensitive to variations in the thickness of the deforming sediment layer than the model proposed by Alley (1990). The differences between the two models examined here highlight the need for a comprehensive comparison of all the methodologies for calculating basal-ice motion currently in use.
\end{abstract}

\section{INTRODUGTION}

Numerical ice-sheet models calculate ice flow by coupling algorithms for internal-ice deformation, and basal-ice motion. Glen's flow law for ice (Glen 1955) is in widespread use and different model formulations of internal ice deformation have been found to produce ice sheets which are in good agreement with one another (Huybrechts and others, 1996). However there are various algorithms available to calculate basal ice-sheet motion (Table 1). Sensitivity tests have been carried out on the response of basal motion to variation in model parameters (Bentley, 1987). However, an intercomparison of ice-stream-sediment-deformation model techniques has yet to be investigated.

Pattyn (1996) performed a flowline experiment comparing basal-motion models based on height-above-buoyancy and subglacial water flux in reconstructing the modern ice flux of the Shirase Glacier, Antarctica. However the flow-line nature of his experiment makes it difficult to generalize the results to a model of a complete ice sheet. Also, there was no long-term geological evidence available to compare the results from the models. In general, the highly multivariate nature of time-dependent ice-sheet models makes it difficult to select a simple comparison methodology to understand how sediment-deformation algorithms affect ice-sheet results. However, several authors have recently investigated the transport of sediment beneath ice sheets using numerical modelling (Jenson and others, 1995, 1996; Dowdeswell and Siegert, 1999). Consequently it is increasingly important to investigate possible discrepancies between the available models for ice-sheet basal motion. This paper aims to highlight the effect of using two different methods for calculating ice-sheet basal motion. The models are applied to determine the sediment delivery to the margin of the Late Weichselian ice sheet in the Barents Sea. There are several features related to this former ice sheet which lend it to the experiment proposed here. First, a new ice-sheet reconstruction of the Late Weichselian Eurasian ice sheet has recently been conducted using the ice-sheet model, and associated environmental inputs, employed here (Howell and others, http://www.ggg.qub.ac. uk [rp05/1999]). Second, the presence of large glacigenic sedimentary fans on the margins of the Barents Sea provides a geological control on the model results. Late Weichselian sediment volumes have been measured on the Bear Island fan and the smaller Storfjorden fan (Laberg, 1996), along the western Barents Sea continental margin (Fig. 1). Third, the presence of the glacigenic sedimentary fans precisely locates the active ice streams which transported the sediment. Interfan margins are characterized by low sediment thicknesses, indicating that the ice sheet terminating in these regions was relatively inactive. Finally, there is currently a thick layer of soft, unconsolidated sediments throughout the Barents Sea. Thus, sediment transport 
Table 1. Methods used to calculate basal ice-sheet motion

\begin{tabular}{|c|c|c|}
\hline Paper & Basal-ice flow model & Key parameters \\
\hline
\end{tabular}

Fowler and Johnson (1996)

Alley $(1990)$

Alley (1990) modified for two-dimension, map-plane, modelling

Pattyn (1996)

Budd and others (1984)

Compares several flowline models;

height-above-buoyancy, water flux.

Lam and Dowdeswell Height-above-buoyancy, flowline model. Motion de(1996)

Van der Veen (1996)

Pattyn (1995)

Hooke and Elverhøi (1995)

Marshall and Clarke (1997)

Jenson and others (1995, 1996)

Pfeffer and others (1997)

Water-flux-based flowline model, driven by water flow, sediment properties and basal shear stress.

Flowline, driven by water flux, by water flow and icesheet basal shear stress.

Pore-water-pressure fixed, motion driven by sediment properties and ice-sheet basal shear stress. pends on depth-dependant effective pressure, sediment strength and basal shear stress.

Height-above-buoyancy, but also allows for time-dependant changes in the friction, $\mu$, of the deformable sediments and lateral drag at the margin of an ice stream.

Temperature-dependant; basal motion dependant on basal stress if above pressure-melting point and is zero if below pressure-melting point.

Temperature-dependant; basal motion dependant on basal stress if above pressure-melting point and is zero if below pressure-melting point.

Subgridcell ice streams, driven by basal temperatures, basal shear stress, marginal shear stress of the ice stream, sediment properties and subglacial water pressure.

Driven by sediment deformation (assuming velocity at the base of the ice sheet equals the velocity at the top of the sediment column).

Sliding driven by sediment properties and externally set parameter.

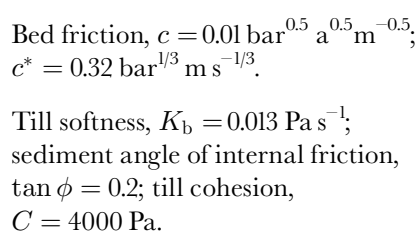

Bed friction, $c=0.01$ bar $^{0.5} \mathrm{a}^{0.5} \mathrm{~m}^{-0.5}$ $c^{*}=0.32 \operatorname{bar}^{1 / 3} \mathrm{~ms}^{-1 / 3}$.

Till softness, $K_{\mathrm{b}}=0.013 \mathrm{~Pa} \mathrm{~s}^{-1}$; sediment angle of internal friction, $\tan \phi=0.2$; till cohesion, $C=4000 \mathrm{~Pa}$

As Alley (1990), but with the fraction of the bed supported by a water film, $f$, set to 0.7 .

Varies.

Till-deformation softness, $5 \times 10^{9} \mathrm{~m} \mathrm{~Pa} \mathrm{a}^{-1}$.

Till-softness coefficient, $9.5 \times 10^{17} \mathrm{~m}^{5} \mathrm{~s}^{-1} \mathrm{~N}^{-2}$.

Sliding parameter,

$A_{\mathrm{S}}=2 \times 10^{-7} \mathrm{~N}^{-2} \mathrm{~m}^{5} \mathrm{a}^{-1}$.

Sliding-law multiplier,

$B=5 \times 10^{-3} \mathrm{~m} \mathrm{a}^{-1} \mathrm{~Pa}^{-1}$.

Sliding parameter, $A=250000 \mathrm{~m} \mathrm{a}^{-1}$

if at pressure-melting point,

$A=0$ otherwise.

$\beta=3 \mathrm{~Pa} \mathrm{a} \mathrm{m}^{-1}$,

bed roughness, $\Omega=0-1$.

Sediment cohesion, $C$, taken to be zero; the sediment angle of internal friction, $\phi=21.8^{\circ}-24^{\circ}$.

Sliding coefficient, $B, B=0.01$ bar $\left(\mathrm{m} \mathrm{a}^{-1}\right)^{-0.5}$; externally set parameter, $\phi$, governing percentage of motion due to basal motion.

\section{$p=2 \quad$ Pore-water Flowline \\ $p=1 \quad$ Pore-water \\ Flowline}

$p=1 \quad$ Pore-water

Varies Varies

Flowline

$p=1 \quad$ HАВ

Map-plane

$p=3 \quad$ HAB

Flowline

$p=3 \quad \mathrm{HAB}$

Map-plane

$p=1 \quad$ Basal-temp.

Map-plane

$p=3 \quad$ Basal-temp.

Flowline

N/A Subgridcell

Map-plane

$p=1.25 \quad$ Sediment-driven

Flowline

$p=2 \quad$ Sediment-driven Map-plane

Notes: Each model is described briefly and the values for important parameters in each model given. All models presented calculate ice-stream motion by using driving stress raised to some power, $p$, in addition to the parameters described. The exponent, $p$, used in each model is given in the table. The models are also grouped by category: "HAB" is a height-above-buoyancy model, "pore-water" indicates that basal flux is driven by pore-water pressure, "basaltemp." denotes ice streams dependant on basal temperature in a given gridcell, "sediment-driven" indicates that basal motion is controlled by sediment properties, and "subgridcell" indicates that ice streams are allowed to occupy less than an entire gridcell. The table also distinguishes between "flowline" models and "map-plane" models.

during the relatively brief Late Weichselian glaciation did not strip the sediment layer from any part of the Barents Sea. Consequently, in modelling sediment deformation during this period, it can be assumed that the actual thickness of easily deformable sediments there exceeded the thickness of the shear zone within the subglacial sediments for the entire Late Weichselian glaciation. Therefore processes of sediment "creation and depletion" need not be considered, and the number of unknowns in the model is thereby reduced.

In summary, we have undertaken an intercomparison of two ice-stream-sediment models by applying the models to the well-documented glaciation of the Barents Sea with specific reference to a well-known glacigenic fan system. The results are valuable in themselves in the context of reconstructing the glacial and sedimentological history of the Barents Sea. The comparison of these two models also acts as an indicator that a more widespread comparison of all the basal-deformation models currently in use is needed.

\section{THE NUMERICAL MODEL}

The Late Weichselian Eurasian ice sheet was modelled using a topographic grid as a boundary condition, consisting of $310(\mathrm{E})$ by $240(\mathrm{~N}) 20 \mathrm{~km} \times 20 \mathrm{~km}$ gridcells covering the United Kingdom, Scandinavia, northern Russia and the Barents and Kara Seas (Fig. 1). A time-dependent, vertically integrated, finite-difference, numerical ice-sheet model was used to determine ice-sheet flow, and an elastic-sheet lithosphere model used to calculate the isostatic depression caused by ice loading. In discrete experiments, the ice-sheet model was coupled to two subglacial sediment-deformation models.

Ice motion within the ice sheet was modelled by solving the continuity equation for ice flow (Mahaffy, 1976);

$$
\frac{\partial h}{\partial}=-\nabla \cdot F(u, h)+b,
$$

where $F(u, h)$ is the net flux of ice out of a cell (via internal 


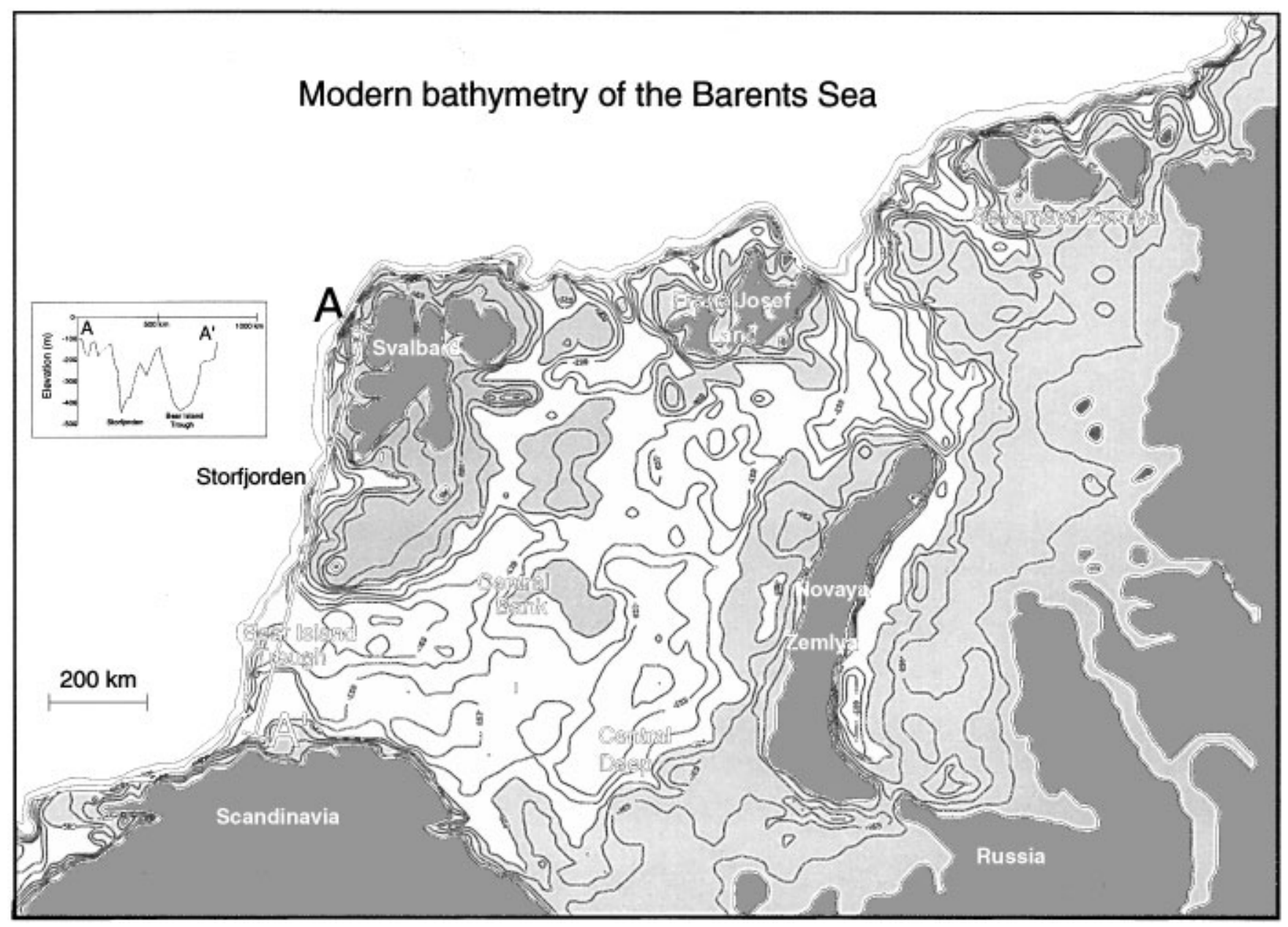

Fig. 1. Modern bathymetry of the Barents Sea (50 m contours). Transect AA', used in experiments on sediment transfer to the western margin of the Barents Sea (Fig. 3) is shown. The current elevation of the transect AA' is given in the inset. Dark shading is land above present sea level, light shading is the area up to $200 \mathrm{~m}$ below present sea level.

deformation and basal motion of the ice sheet), and depends on ice-sheet thickness, $h$ and velocity, $u$. The mass budget term, $b$, incorporates a number of processes including surface accumulation and ablation, iceberg calving and iceshelf basal melting. Equation (1) is solved using an implicit finite-difference technique (Huybrechts and others, 1996).

Internal ice-sheet deformation is modelled using a depth-averaged ice-velocity equation;

$$
\bar{u}_{x}=\frac{s A}{n+2}\left(\tau_{\mathrm{b} x}^{2}+\tau_{\mathrm{b} y}^{2}\right)^{\frac{n-1}{2}} \tau_{\mathrm{b} x} h
$$

where

$$
\tau_{\mathrm{b} x}=-\rho_{\mathrm{i}} g h \sin \alpha_{x}
$$

and $\tau_{\mathrm{b} x}$ is the basal shear stress in the $x$ direction, dependent on ice thickness, $h$, acceleration due to gravity $\left(g=9.81 \mathrm{~m} \mathrm{~s}^{-1}\right)$, density of ice $\left(\rho_{\mathrm{i}}=910 \mathrm{~kg} \mathrm{~m}^{-3}\right)$ and ice-sheet surface slope, $\alpha_{x}$ (Paterson, 1994). $A$ is a flow-law parameter, here taken to be a constant $\left(10-16 \mathrm{~Pa}^{-3} \mathrm{a}^{-1}\right)$ after (Huybrechts and others, 1996), and the flow-law exponent used, $n=3$. Similar equations apply for motion in the $y$ direction.

Modelling isostatic bedrock adjustment is after Oerlemans and Van der Veen (1984) and Le Meur and Huybrechts (1996). The Earth is modelled as a two-layer system, with an elastic lithosphere controlling the final isostatic depression and an underlying relaxed asthenosphere controlling the time taken to reach the equilibrium position. The lithosphere is modelled as an elastic sheet where an equilibrium depression caused by a discrete load at a point $x=0$, is given by

$$
w(x)=\frac{1}{2 \pi D} q_{x} \Lambda^{2} \chi\left(x^{\prime}\right)
$$

where

$$
x^{\prime}=\frac{|x|}{\Lambda}
$$

and

$$
\Lambda=\left(\frac{4 D}{\rho_{\mathrm{m}} g}\right)^{\frac{1}{4}}
$$

In Equations (3a)-(3c), $x$ is the distance from the applied load, $\rho_{\mathrm{m}}$ is the density of the mantle $\left(3300 \mathrm{~kg} \mathrm{~m}^{-3}\right), q_{x}$ is the magnitude of the applied load, $D$ is the flexural rigidity of the lithosphere, and $\chi$ is a Kelvin function of zero order. Fjeldskaar (1994) determined that the flexural rigidity in Scandinavia was between $1 \times 10^{24}$ and $1 \times 10^{26} \mathrm{~N}$ m. Our study uses a flexural-rigidity value of $1 \times 10^{25} \mathrm{~N} \mathrm{~m}$. Equation (3a) is linear and, therefore, the total deflection of the lithosphere can be approximated as the sum of the deflections caused by discrete loads in each cell. The lithosphere is allowed to approach the equilibrium deflection computed in Equation (3a) by a exponential decay (Le Meur and Huybrechts, 1996):

$$
\frac{\mathrm{d} B}{\mathrm{~d} t}=\frac{1}{\phi}\left(B_{\mathrm{o}}-w_{\mathrm{b}}-B\right)
$$



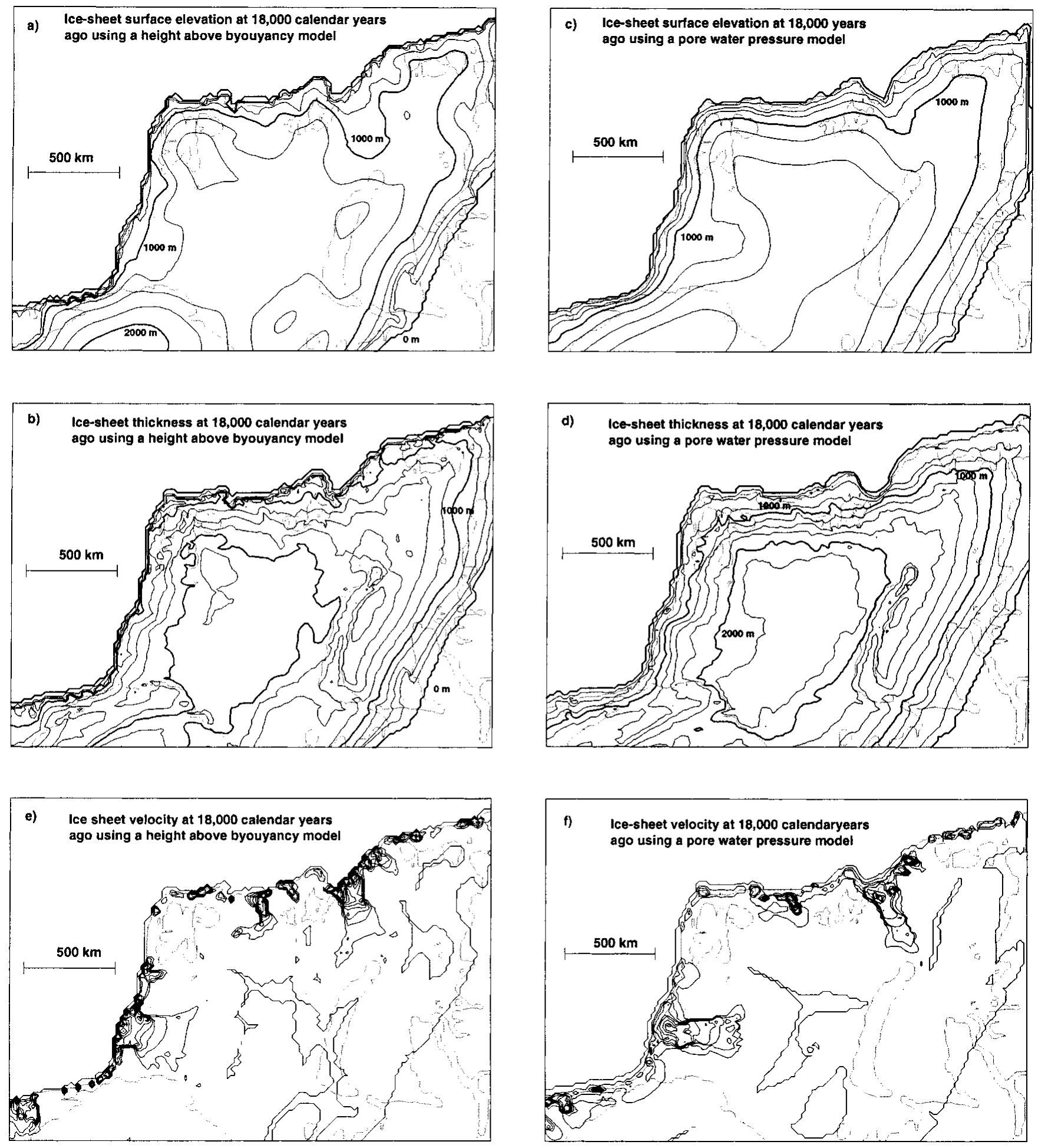

Fig. 2. The Eurasian High Arctic ice sheet modelled at the LGM. Using the height-above-buoyancy model: (a) Ice-sheet surface elevation (250 m contours); (b) ice-sheet thickness (250 m contours); (c) ice-sheet velocity (100 $\mathrm{m} \mathrm{a}^{-1}$ contours). Using the porewater-pressure model of Alley (1990): (d) ice-sheet surface elevation (250 m contours); ( e) ice-sheet thickness (250 m contours); (f) ice-sheet velocity (100 $\mathrm{ma}^{-1}$ contours).

where $B$ is the bedrock profile at time $t, B_{\mathrm{o}}$ is the original bedrock profile, $w_{\mathrm{b}}$ is the bedrock depression from the original non-glaciated state, calculated from Equation (3a), and $\phi$ is a characteristic time constant governing the rate at which isostatic adjustment occurs. In each model year the lithosphere is adjusted by $1 / \phi$ times the distance to equilibrium (Equation (4)). In this paper $\phi$ is taken as 3000 years (Le Meur and Huybrechts, 1996). The value of 3000 years is compatible with that determined by Fjeldskaar (1994) from Scandinavia, and with the raised-beach uplift data from the
Barents Sea summarized by Lambeck (1995). This approach allows for modelling isostatic depression beneath the ice sheet, as well as more distal effects, including forebulges. The ice-sheet model described here is relatively insensitive to small changes in the environmental forcing parameters (Howell and others, ggg[rp05/1999]).

\section{ENVIRONMENTAL GONDITIONS}

Modelled ice-sheet growth is controlled by a number of en- 
vironmental forcing functions. Spatially and temporally varying temperature and precipitation regimes have a significant effect on ice-sheet development. Global sea-level change is also influential in controlling the extent and growth of the ice sheet. These parameters are input as forcing functions into the ice-sheet model. However, in previous experiments, these inputs have been demonstrated to yield an ice sheet that is compatible with geological data relating to the extent of the last ice sheet (Howell and others, ggg[rp05/1999]).

\section{Sea-level depression}

The time-dependent change in sea level, adapted from Fairbanks (1989) and Shackleton (1987), is used to describe the variation in sea level during the last glacial cycle. The sealevel function has been corrected by the Bard and others (1990) calibration so that it is in calendar years (Siegert and Dowdeswell, 1995). Our model therefore runs in calendar years. The sea-level curve is used to adjust bedrock heights through time, and to parameterize the transition between modern and glacial-maximum temperatures. Fullglacial conditions are assumed to coincide with maximum global sea-level depression, while modern sea level is correlated with modern climatic conditions.

\section{Palaeoenvironmental conditions}

The accumulation regime employed in this paper is identical to the one presented in Howell and others ( $\operatorname{ggg}[\mathrm{rp05} / 1999]$ ). There is a lack of data concerning the climatic regime of the Eurasian Arctic during the Late Weichselian. However, in previous experiments we employed an inverse-modelling procedure to produce an estimate of the accumulation regime throughout the Late Weichselian. Modern temperature and precipitation regimes have been established using the data presented by Vose and others (1992). An initial estimate of the Last Glacial Maximum (LGM) temperature regime was obtained by adjusting modern values using the latitude-dependent variations proposed by Manabe and Broccoli (1985). The transition between modern and glacial-maximum conditions was parameterized using the sea-level curve of Fairbanks (1987) and Shackleton (1987). The ice-sheet model was run using the initial estimate for climatic conditions, and the resulting ice-sheet limits were compared with those determined from geological observations. Changes were then made to the LGM temperature- and precipitation-regime end members to improve the correlation between the modelled and geologically determined ice-sheet limits. This process was iterated until a satisfactory match was obtained, as described in Howell and others (ggg[rp05/1999]).

\section{METHODOLOGY}

We use a time-dependent ice-sheet model, linked to a sediment-deformation model, to investigate the effect of different ice-stream models on glacigenic deposits for the Late Weichselian Barents Sea. The positioning of glacigenic sedimentary fans at the mouths of bathymetric troughs in the Eurasian High Arctic suggests that topographically controlled ice streams were the dominant factor in draining ice from the Barents Sea. Thus, any ice-stream model used in the context of the Barents Sea must locate ice-stream activity within major cross-shelf troughs. The existence of substantial glacigenic deposits also indicates that subglacial deformation was the dominant mechanism by which basal motion of the ice streams occurred and consequently basal sliding of the ice sheet is assumed to be negligible. These constraints make the glaciation of the Late Weichselian Barents Sea an ideal case study for conducting comparative tests on different ice-stream-sediment models.

The types of model available to simulate basal motion of an ice sheet are indicated in Table 1 . The methods described may be broadly classified into height-above-buoyancy, subglacial-pore-water-pressure, basal-temperature and sediment-properties models. In addition, all of the models use the shear stress at the base of the ice sheet as a controlling factor on basal motion. As indicated in Table 1 some of these models are only suitable for flowline modelling (e.g. Alley, 1990), and require modification to work in a map-plane reconstruction of an entire ice sheet. Furthermore, map-plane versions of models driven entirely by sediment properties (e.g. Jenson and others, 1995, 1996; Pfeffer and others, 1997) require ice-stream locations to be explicitly defined both spatially and temporally. The simple vertically integrated icesheet model employed here is isothermal in nature, that is, it cannot calculate basal temperature dynamically. As a consequence it is unsuitable for examining basal-motion models which rely on basal-temperature calculations (e.g. Payne, 1995; Marshall and Clarke, 1997). However the icesheet model employed here is suitable for examining the two most widely used classes of models, where basal motion is dependant on height-above-buoyancy or pore-water pressure. In order to concentrate on the differences between the two classes of models, rather than specifics of each individual model, we have selected simple examples of each class of model for the experiments conducted here. We stress that this work should be seen as the beginning of a process of intercomparison of models, rather than an isolated exercise.

Two different experiments were designed, using independent methods for calculating basal motion beneath an ice stream: (1) using a height-above-buoyancy method (Budd and others, 1984); and (2) a modified version of Alley's (1989, 1990) pore-water, pressure-driven, ice-stream model. In each case the basal motion was coupled with a depthaveraged sediment-deformation model. The ice-sheet model was run from the onset of glaciation until the initiation of glacial retreat, providing a calculation of the total sediment volume delivered to the edge of the continental shelf during the Late Weichselian. Sediment volumes deposited on trough mouth fans on the western margin of the Barents Sea during the Late Weichselian have been measured, indicating that approximately $4000 \mathrm{~km}^{3}$ of sediments were delivered to the Bear Island fan, and $700 \mathrm{~km}^{3}$ were deposited on the Storfjorden fan (Laberg, 1996). These estimates of sediment accumulation were compared with the sediment volume predicted by each model.

A full set of sensitivity tests was performed for each model to examine the effects of varying key parameters within the ice-stream and sediment models on sediment volume.

\section{Height-above-buoyancy model}

The first method for modelling basal motion of the ice sheet uses a height-above-buoyancy model to calculate effective pressure at the base of the ice sheet, and hence the basal velocity:

$$
u_{\mathrm{s} x}=\frac{K \tau_{\mathrm{b} x}}{N_{\mathrm{e}}^{2}}
$$


where

$$
N_{\mathrm{e}}^{2}=\rho_{\mathrm{i}} g h_{\mathrm{e}}
$$

and $N_{\mathrm{e}}$ is the effective pressure, $h_{\mathrm{e}}$ is the height of the ice sheet above buoyancy and $K$ is the till-deformation softness $\left(5 \times 10^{9} \mathrm{~m} \mathrm{~Pa} \mathrm{a}^{-1}\right)$ (Budd and others, 1984). This basal-motion relationship is only valid for marine-based portions of the ice sheet, where buoyancy effects can operate, because height-above-buoyancy models produce basal velocities that are strongly dependent on water depth. Thus, ice streams are predicted within bathymetric submarine troughs.

Sediment transport is calculated by producing a depthaveraged sediment-deformation velocity, $\bar{u}_{\text {sed, }}$ which is related to the velocity at the top of the sediment column by:

$$
\bar{u}_{\text {sed }}=z u_{\mathrm{s}}
$$

Where $z$ is a depth averaging factor $(0<z<1)$. We make a simplifying assumption that there is no significant exchange of sediment between the till layer and the basal-ice layer of the ice sheet. Consequently sediment flux can be modelled using a continuity equation, similar in form to the continuity equation for the ice sheet (Equation (1)).

It is assumed that the velocity at the top of the deforming-sediment layer is equal to the velocity at the base of the ice (i.e. all basal motion occurs through sediment deformation rather than ice-sheet sliding). At some depth, $h_{\mathrm{b}}$, within the sediment column, sediment-deformation rates will equal zero. The thickness of the layer of water-saturated sediments beneath Ice Stream B, Antarctica, has been found to be around $6 \mathrm{~m}$ (Blankenship and others, 1986, 1987). However modelling has suggested that, away from the margin of an ice sheet, the deforming thickness may be less than $6 \mathrm{~m}$ (Murray, 1990). Boulton and Hindmarsh (1987) suggested that most of the deformation within the sediment column occurs near the top of the sediment column. In order to account for this concentration of velocity at the top of the sediment column we use a deforming-sediment thickness, $h_{\mathrm{b}}$, of $5 \mathrm{~m}$ in the initial experiment combined with a depth-averaging factor, $z$, of 0.2. The combination of these values are in line with Hooke and Elverhøi (1996) who used $h_{\mathrm{b}}=4$ and $z=1 / 3$, and Dowdeswell and Siegert (1999) who used $h_{\mathrm{b}}=2$ and $z=0.5$. The response of the sediment model to variations in $h_{\mathrm{b}}$ and $z$ are then subjected to extensive sensitivity testing.

As already noted the presence of pre-LateWeichselian soft sediments beneath subglacial till throughout the entire Barents Sea indicates a greater availability of deformable sediment than was actually mobilized during the Late Weichselian. We therefore assume that the depth of deforming sediment, $h_{\mathrm{b}}$, remained constant throughout the model run.

\section{Pore-water-pressure model}

The second method is based on that outlined by Alley (1989, 1990), where subglacial pore water is used to calculate the effective pressure, $N_{\mathrm{e}}$, at the base of the ice sheet:

$$
N_{\mathrm{e}}=\frac{\beta \tau_{\mathrm{b}}}{f}
$$

where $\beta$ is a dimensionless roughness coefficient $(0.45$ from Alley, 1990), and $f$ is the fraction of the bed supported by a water film. For a till bed, as in the case of the Barents Sea, Alley (1989) estimates $f$ as:

$$
f=1+0.1 \log _{10} d
$$

where $d$ is the thickness of the subglacial-water film in metres. Alley (1989) notes that the water film beneath fast moving glaciers is likely to be on the order of $1-10 \mathrm{~mm}$, giving $f \approx 0.7$. Ice-sheet basal velocity is related to effective pressure by:

$$
\begin{aligned}
u_{\mathrm{s} x} & =\frac{h_{\mathrm{b}} K_{\mathrm{b}}\left(\tau_{\mathrm{b} x}-\tau^{*}\right)}{N_{\mathrm{e}}^{2}} \\
\tau^{*} & =N_{\mathrm{e}} \tan \phi+C
\end{aligned}
$$

where $K_{\mathrm{b}}$ is a till-softness coefficient (taken as $0.013 \mathrm{~Pa} \mathrm{~s}^{-1}$, after Alley, 1990), $C$ is the till cohesion constant $(4 \mathrm{kPa}), \phi$ is the angle of internal friction $(\tan \phi=0.2$, after Alley, 1990), and $h_{\mathrm{b}}$ is the deforming-till thickness. In the initial experiment we assume that ice-stream motion, within bathymetric troughs, occurs with $f=0.7$. We also assume that no significant ice-sheet basal motion occurs outside the trough areas. This assumption is justified by noting that the glacially transported material at the margins of the Barents Sea is concentrated in trough-mouth fans. The effects of using different values for $f$ and $\beta$ are examined in sensitivity tests.

Sediment deformation is calculated using the same assumptions as for the height-above-buoyancy model. To keep the comparison between models as close as possible, the initial experiment uses a deformable sediment layer, $h_{\mathrm{b}}, 5 \mathrm{~m}$ thick, with a depth-averaged velocity, $z$, equal to 0.2 of the ice-sheet basal velocity. The effects of variations in these parameters on sediment delivery to the continental margin are examined in sensitivity tests.

\section{RESULTS}

\section{Height-above-buoyancy model}

The ice-sheet thickness and surface elevation produced for the Late Weichselian maximum in the Eurasian Arctic using the height-above-buoyancy model are shown in Figure $2 \mathrm{a}, \mathrm{b}$ and $\mathrm{c}$. The ice sheet produced in this reconstruction is the same as the one presented in Howell and others (ggg[rp05/1999]). Ice-sheet growth was initiated over Scandinavia and the High Arctic archipelagos, and is predicted to have expanded into the shallow marine Barents Sea by around 27000 years ago. Glaciation of the Barents Sea was by means of ice flowing west from Novaya Zemlya, south from Svalbard and Franz Josef Land, and north and northeast from Scandinavia. The Barents Sea was fully covered with grounded ice by 25000 years ago, and continued to thicken throughout the Late Weichselian. This increase in ice-sheet thickness led to the initiation of ice-stream activity in the Storfjorden Trough by 25000 years ago, and the Bear Island Trough by 23000 years ago. Ice-stream velocities rapidly increased to near their maximum by 21000 years ago, with the Bear Island ice stream flowing at up to $1000 \mathrm{~m} \mathrm{a}^{-1}$, and $>500 \mathrm{~m} \mathrm{a}^{-1}$ in the Storfjorden Trough (Fig. 2c). By the glacial maximum at 18000 years ago the entire Barents and Kara Seas were fully glaciated, with ice thicknesses of about $2000 \mathrm{~m}$ in the Barents Sea and $1400 \mathrm{~m}$ in the Kara Sea. Ice divides occurred on high areas over Svalbard (1400 m a.s.l.), Novaya Zemlya (1500 m a.s.l.) and Scandinavia. Ice flowed westwards from Novaya Zemlya into the Barents Sea and, subsequently, towards the continental margin. Ice flow out of the ice sheet was concentrated in the Bear Island Trough, resulting in a significant lowering of the surface elevation of the ice sheet in this region (Fig. 2a).

The sediment volume transported across a transect along the continental margin for the Late Weichselian is 


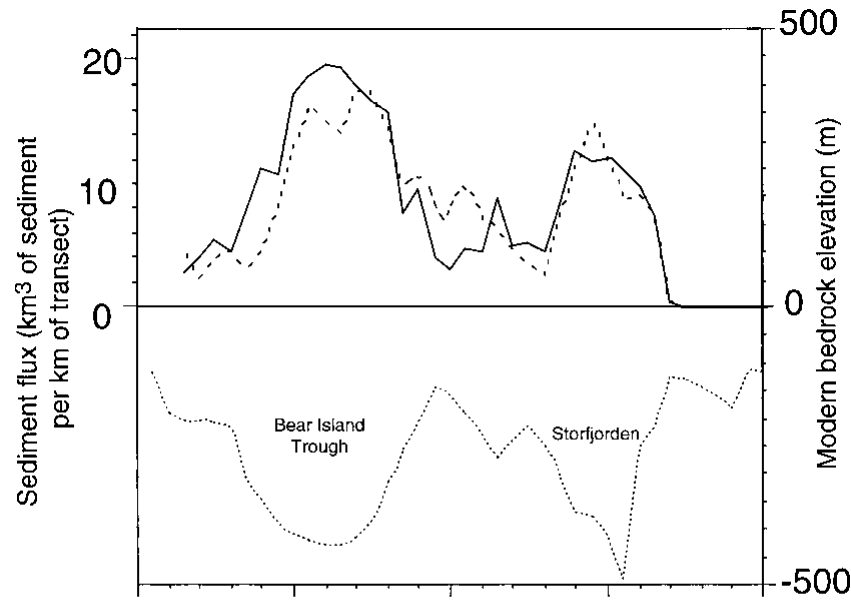

Fig. 3. Predicted sediment flux delivered across transect $A A^{\prime}$ (Fig. 1) during the Late Weichselian (in $\mathrm{km}^{3} / \mathrm{km}$ ) using a height-above-buoyancy model and the pore-water-pressure model of Alley (1990). The modern bathymetry ( $m$ below sea level) is also shown for reference.

shown in Figure 3. The location of the transect is indicated in Figure 1. The mouth of the Bear Island Trough is the main region of sediment development, with $4200 \mathrm{~km}^{3}$ of sediments delivered to the continental margin during the Late Weichselian. We do not model sediment dispersal beyond the ice-sheet margin, rather it is assumed that the sediments delivered to the continental margin are then distributed over the Bear Island Trough mouth fan by a combination of gravity and current-driven processes. The Storfjorden fan is calculated to have received just over $900 \mathrm{~km}^{3}$ of sediments during the Late Weichselian.

Sediment delivery under the height-above-buoyancy model is controlled by a number of parameters, most notably the depth-averaging function for till velocities, the thickness of the actively deforming sediment layer and the till-deformation softness, $K$. The sensitivity of the sediment volume to variation in these factors is shown in Figure 4. The model is pseudo-linearly sensitive to the thickness of the deforming sediment and the depth-averaging factor. This result is unsurprising, since basal motion of the ice sheet is not dependent on either factor (Equation (9a)), and consequently there is no feedback involved. The sediment volume is somewhat sensitive to the sediment-deformation softness-parameter, $K$, but small changes $( \pm 20 \%)$ to $K$ do not result in the predicted sediment volumes on Bear Island lying outside realistic limits.

\section{Pore-water-pressure model}

The ice-sheet thickness, surface elevations and velocity predicted for the Late Weichselian maximum in the Eurasian Arctic using the modified Alley (1990) pore-water-pressure model are shown in Figure 2d, e and f. Ice-sheet growth during the Late Weichselian is similar to that predicted for the height-above-buoyancy model. By 18000 years ago the entire Barents and Kara Seas are predicted to have been fully glaciated, with ice thicknesses of up to $2000 \mathrm{~m}$ in the Barents Sea and $1400 \mathrm{~m}$ in the Kara Sea. Note that the ice sheet produced using this basal-motion regime is broadly similar to that produced by the height-above-buoyancy model described above, with a similar depression of the surface caused by high ice fluxes from an ice stream in the Bear Island Trough. The ice sheet also exhibits spreading centres on Svalbard, Novaya Zemlya and Scandinavia, just as the height-abovebuoyancy based reconstruction does, although there are small differences in the precise configuration of the two ice sheets
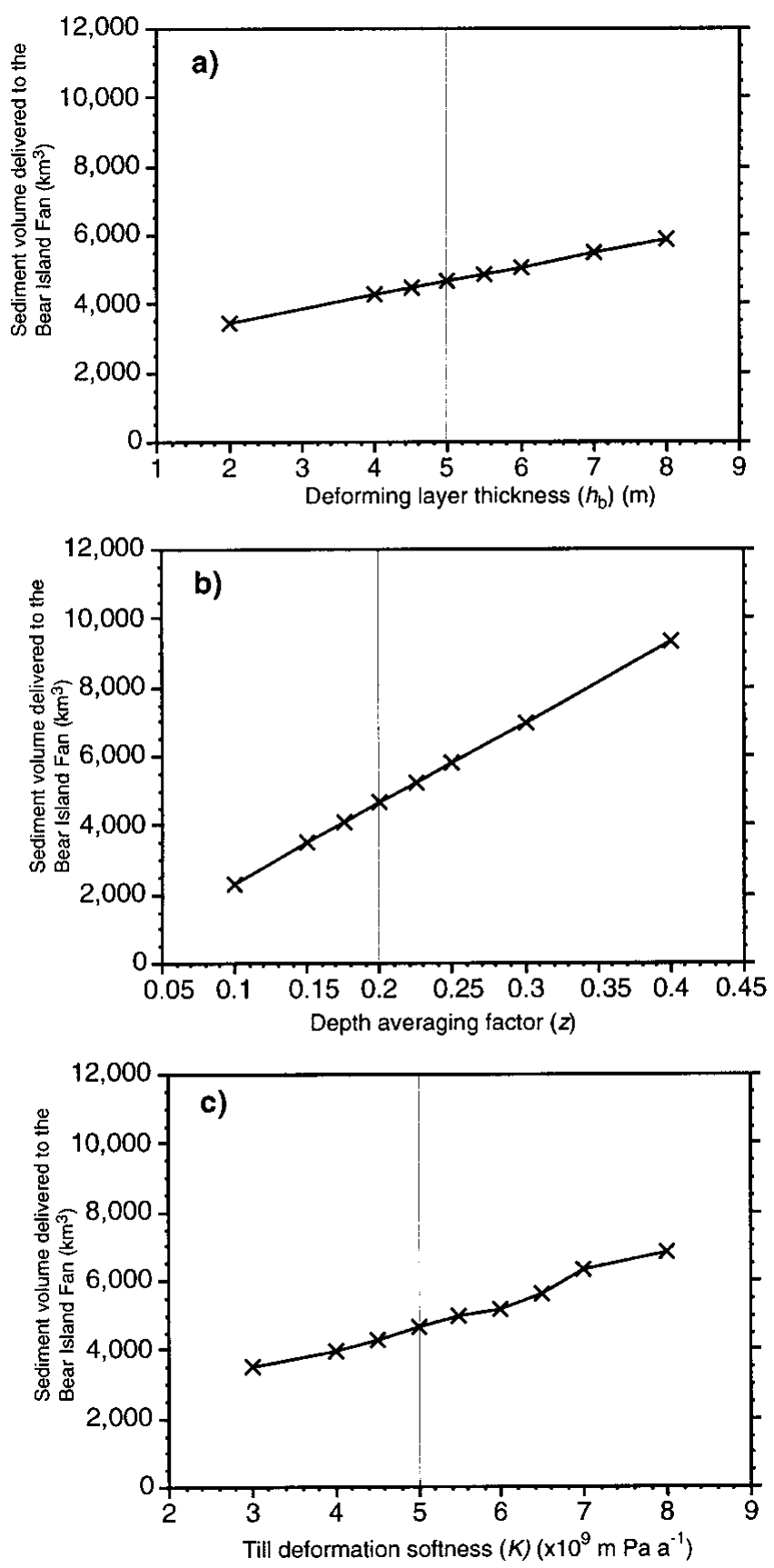

Fig. 4. Sensitivity of the volume of sediments $\left(\mathrm{km}^{3}\right)$ to changes in model parameters for the height-above-buoyancy model calculated for the Bear Island fan. (a) Changes in sediment volume $\left(\mathrm{km}^{3}\right)$ due to changes in the thickness of the deforming layer of sediments $(\mathrm{m})$. ( $b$ ) Changes in sediment volume $\left(\mathrm{km}^{3}\right)$ due to changes in the depth-averaging factor used. (c) Changes in sediment volume $\left(\mathrm{km}^{3}\right)$ due to changes in the till deformation softness $\left(m \mathrm{~Pa} \mathrm{a}^{-1}\right)$. The vertical line indicates the standard value used in these experiments. 

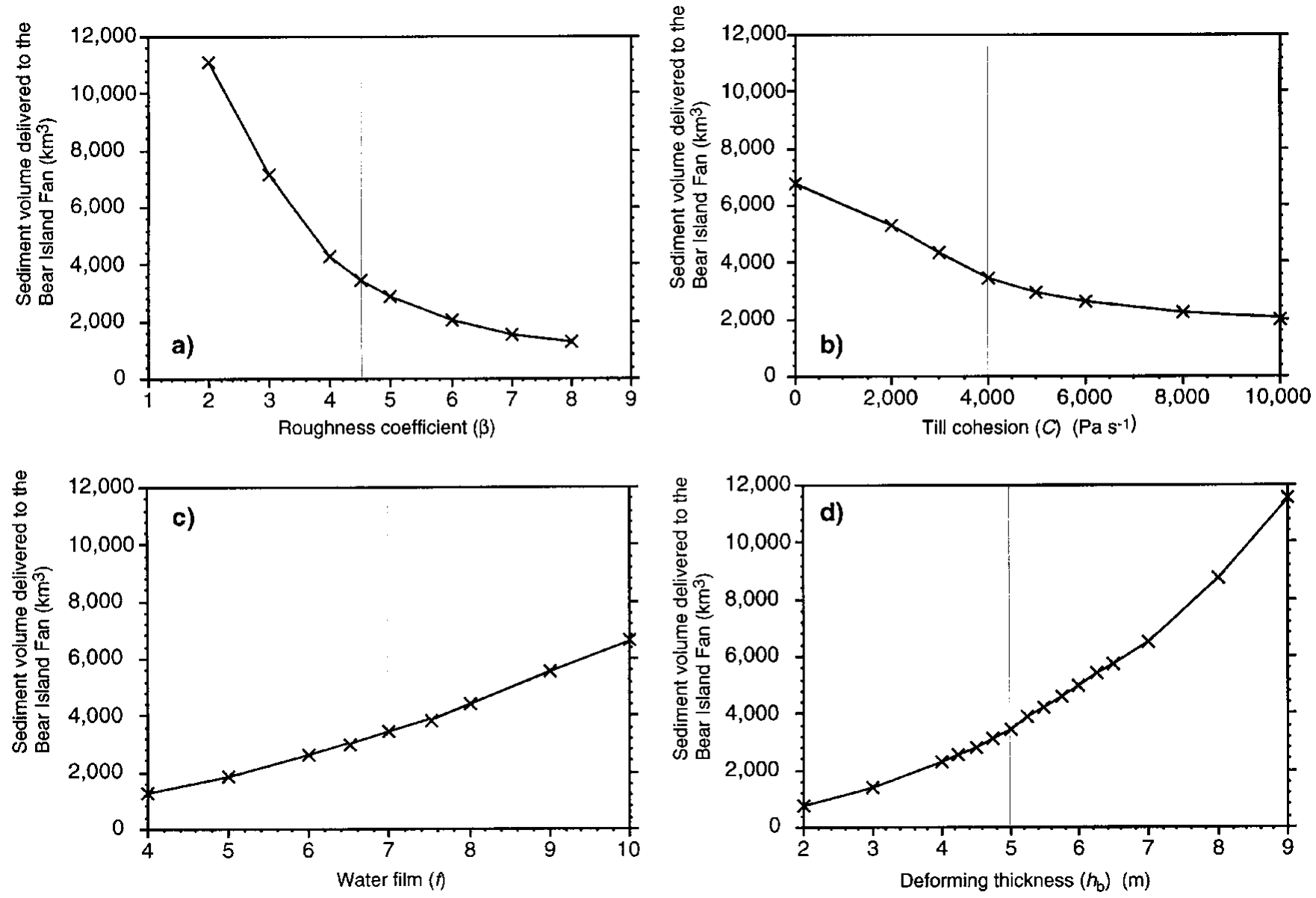

Fig. 5. Sensitivity of the volume of sediments $\left(\mathrm{km}^{3}\right)$ to changes in model parameters for the Alley (1990) sediment model predicted for the Bear Island fan. (a) Changes in sediment volume $\left(\mathrm{km}^{3}\right)$ due to changes in the roughness coefficient. (b) Changes in sediment volume $\left(\mathrm{km}^{3}\right)$ due to changes in the till-cohesion constant. (c) Changes in sediment volume $\left(\mathrm{km}^{3}\right)$ due to changes in the fraction of the bed supported by a water film. (d) Changes in sediment volume $\left(\mathrm{km}^{3}\right)$ due to changes in the thickness of the deforming layer of sediments $(m)$. The vertical line indicates the standard value used in these experiments.

as a result of the different basal-motion regime employed. Thus changes to the ice-stream model do not yield significantly different results.

Modelled sediment delivery to the western continental margin of the Barents Sea is summarized in Figure 3. Approximately $3800 \mathrm{~km}^{3}$ of sediment are delivered to the Bear Island fan, $\sim 10 \%$ less than the $4,200 \mathrm{~km}^{3}$ predicted under the height-above-buoyancy model. The pore-water-pressure model (Alley, 1990) predicts around $1000 \mathrm{~km}^{3}$ of sediment at the margin of the Storfjorden Trough, slightly higher than for the height-above-buoyancy model. This is somewhat higher than the $700 \mathrm{~km}^{3}$ given by Laberg (1996), but is still in reasonably good agreement. Differences between the two models are most marked in the region between the Storfjorden and Bear Island fans, where ice velocities are lowest in both cases. The models are in reasonably close agreement in regions of high ice velocities.

The volume of sediment predicted to be delivered to the continental margin by the pore-water-pressure model is sensitive to the roughness coefficient, $\beta$ (Fig. $5 \mathrm{a}$ ), the till cohesion, $C$ (Fig. 5b), the fraction of the bed supported by a water film, $f$ (Fig. 5c), and the thickness of the actively deforming sediment layer (Fig. 5d). As with the height-above-buoyancy method, there is no feedback from the depth-averaging factor into the icesheet model, and consequently sediment delivered depends linearly on the depth-averaging factor used (Fig. 5). However the basal-ice velocity in the pore-water-pressure model is depen- dent on the thickness of the deforming layer and consequently there is a non-linear relationship between these two variables (Fig. 5). It can be seen that the model is relatively insensitive to changes $( \pm 50 \%)$ in the depth of the deforming layer. Deforming thicknesses, $h_{\mathrm{b}}$, of between $4.5 \mathrm{~m}$ and $6 \mathrm{~m}$ (combined with a depth-averaging parameter, $z$, of 0.2 ) yield sediment volumes broadly in line with the geological evidence. The sediment volume is somewhat sensitive to the till cohesion, $C$, where an increase of $50 \%$ results in $30 \%$ less sediment reaching the continental margin. A reduction of $50 \%$ in $C$ produces $40 \%$ more sediment at the margin. Increases in the till cohesion beyond these ranges results in relatively little further change in sediment yield, however neglecting till cohesion entirely produces unrealistically high sediment volumes with some $6800 \mathrm{~km}^{3}$ of sediment being delivered to the Bear Island fan. The model is also sensitive to the fraction of the bed supported by a water film $f$, where an increase of $10 \%$ in $f$ results in $20 \%$ more sediment yield, and a reduction of $10 \%$ in $f$ lowers sediment yield by around $15 \%$. Sediment yield also depends inversely on the roughness coefficient $\beta$ (Fig. 5a). Small decreases $(<10 \%)$ in $\beta$ have relatively little effect on the sediment volumes, however decreasing $\beta$ by more than $10 \%$ results in unrealistically easy deformation of the basal sediments, and consequent large increases in sediments transported to the continental margin (a sediment volume of $7200 \mathrm{~km}^{3}$ on the Bear Island fan for $\beta=0.2$ ). Increasing $\beta$ has much less of an effect on sediment yields. 


\section{SUMMARY AND CONCLUSIONS}

The Late Weichselian Barents Sea ice sheet was underlain by soft deforming sediments, which were transported to the continental margins where they accumulated as large fans. A number of geophysical datasets are available from which measurements of the sediment volume over the Bear Island Trough $\left(4000 \mathrm{~km}^{3}\right)$ and Storfjorden Trough $\left(700 \mathrm{~km}^{3}\right)$ fans can be made. These measurements provide ideal geological data to test and compare models of ice-stream-sediment delivery.

We have used two different models for basal ice-sheet motion and sediment transport to reconstruct sediment delivery to the western continental margin of the Barents Sea during the Late Weichselian: (1) a height-above-buoyancy model and (2) a model based on the approach of Alley (1990). These experiments allow an intercomparison of the respective models. Both are able to reproduce the observed volume of Late Weichselian sediment on the Bear Island fan accurately. The model results exhibit a degree of sensitivity to geotechnical properties of the deforming sediment, for which relatively little real-world control data exist. Both models depend on the till-deformation softness, while the Alley (1990) model also incorporates the internal angle of friction. The velocity profile within the deforming sediments is also crucial to both models and is the subject of some uncertainty. However, neither model is highly sensitive to small changes in the major model parameters and, for both, changes to key parameters within a realistic range of values do not result in predictions incompatible with available geological data.

The two models presented here are dependent on different parameters, with the height-above-buoyancy model being dependent on the till softness, till depth, sediment-velocitydepth-averaging factor, basal shear stress of the driving ice sheet and topographic depth. The Alley (1990) model also depends on basal shear stress, till thickness, sediment-velocitydepth-averaging factor and a till-softness coefficient. However, the angle of internal friction within the till, the sediment roughness, and the fraction of the ice-sheet bed supported by a water film also influence ice-sheet motion and sediment transport in the Alley (1990) model, whereas they are not accounted for in the height-above-buoyancy model used here. Although both models incorporate a till-softness coefficient, this is formulated in different ways for the two models. The Alley (1990) model defines till softness as a coefficient with units of $\mathrm{Pa} \mathrm{s}^{-1}$, while the height-above-buoyancy model defines till softness as a coefficient with units of $\mathrm{m} \mathrm{Pa} \mathrm{a}^{-1}$. This discrepancy arises from differences in the formulation of sediment velocity in the two models (Equations (5) and (9)). Furthermore, the way in which sediment volumes vary according to changes in key parameters differs between the models. In particular, the models exhibit different responses to changes in the thickness of the layer of actively deforming sediments, $h_{\mathrm{b}}$. The height-above-buoyancy model is linearly dependent on $h_{\mathrm{b}}$ (Fig. 4a), while the Alley (1990) model is non-linearly dependent on $h_{\mathrm{b}}$, and is more highly sensitive to increases in the thickness (Fig. 5d). For example, if the depth-averaging parameter, $z$, is held constant at 0.2 , a change from $h_{\mathrm{b}}=2 \mathrm{~m}$ to $h_{\mathrm{b}}=$ $4 \mathrm{~m}$ in the height-above-buoyancy model results in an increase in sediment volumes on the Bear Island fan of $810 \mathrm{~km}^{3}$, compared with $1518 \mathrm{~km}^{3}$ for the Alley (1990) model. However a change from $h_{\mathrm{b}}=6 \mathrm{~m}$ to $h_{\mathrm{b}}=8 \mathrm{~m}$ in the height-above-buoyancy produces $818 \mathrm{~km}^{3}$ more sediment, compared with an increase of $3782 \mathrm{~km}^{3}$ for the Alley (1990) model. Compared to the heightabove-buoyancy, the Alley (1990) model is more sensitive to changes in the thickness of the deforming sediment layer, and is more sensitive at greater deforming layer thicknesses.

A number of other conclusions relating to the model intercomparison are:

(1) The geographical pattern of sedimentation is similar, though not identical, in the two models. Both models produce large volumes of sediment in the Bear Island and Storfjorden Troughs, and relatively smaller amounts in the interfan region. For the Bear Island fan the heightabove-buoyancy model produces $12 \%$ more sediment $\left(4200 \mathrm{~km}^{3}\right)$ than the Alley (1990) model. The Alley model (1990) produces $10 \%$ more sediment than the height-above-buoyancy on the Storfjorden fan $\left(1000 \mathrm{~km}^{3}\right)$. Thus, the two models broadly agree on their predictions for sediment volume delivered to the major fan systems on the western margin of the Barents Sea.

(2) A higher degree of disagreement is found in regions where the sedimentation rate is lowest (i.e. small fans and interfan regions). For the region between the major Bear Island and Storfjorden fans, the Alley (1990) model produces $28 \%$ more sediment than the height-above-buoyancy model, much greater than the $10 \%$ and $12 \%$ differences for the major fan systems.

(3) The location and ice velocities of major ice streams predicted by both models is broadly similar, with fast-flowing ice in the Bear Island Trough and the Storfjorden Trough, with slower-moving ice in between. The heightabove-buoyancy model predicts ice velocities up to $1000 \mathrm{~m} \mathrm{a}^{-1}$ in the Bear Island Trough, and $500 \mathrm{~m} \mathrm{a}^{-1}$ in the Storfjorden Trough, with localized velocities of up to $200 \mathrm{~m} \mathrm{a}^{-1}$ northwest of Bear Island. Much slower moving ice $\left(<50 \mathrm{~m} \mathrm{a}^{-1}\right)$ characterized the rest of the continental margin. The Alley (1990) model predicted ice flowing at around $1000 \mathrm{~m} \mathrm{a}^{-1}$ in the Bear Island Trough, and $600 \mathrm{~m} \mathrm{a}^{-1}$ in the Storfjorden Trough. Velocities elsewhere on the western margin were of the order of tens of metres per year, except for localized fluxes northwest of Bear Island and off northwest Svalbard.

In a small study of this kind it has obviously not been possible to compare all the available models for ice-sheet basal motion. The experiments performed here highlight the need for a large-scale review of the similarities and differences in reconstructed ice sheets produced by the different methodologies. This comparison should include more classes of models than in this preliminary study, more examples from each class, and may best be done as an analogue to the modelled internal ice-sheet dynamics testing exercises carried out as part of the European Ice Sheet Modelling Initiative (EISMINT) program (Huybrechts and Payne, 1996).

\section{AGKNOWLEDGEMENTS}

D. H. acknowledges receipt of a $\mathrm{PhD}$ studentship from the University of Wales, Aberystwyth.

\section{REFERENGES}

Alley, R. B. 1989. Water-pressure coupling of sliding and bed deformation: I. Water system. f. Glaciol., 35(119), 108-118.

Alley, R. B. 1990. Multiple steady states in ice--water-till systems. Ann. Glaciol., 14, 1-5.

Bard, E., B. Hamelin and R. G. Fairbanks. 1990. U-Th ages obtained by mass spectrometry in corals from Barbados: sea level during the past 
130,000 years. Nature, 346(6283), 456-458.

Bentley, C. R. 1987. Antarctic ice streams: a review. 7. Geophys. Res., 92(B9), 8843-8858.

Blankenship, D. D., C. R. Bentley, S. T. Rooney and R. B. Alley. 1986. Seismic measurements reveal a saturated porous layer beneath an active Antarctic ice stream. Nature, 322(6074), 54-57.

Blankenship, D. D., C. R. Bentley, S. T. Rooney and R. B. Alley. 1987. Till beneath Ice Stream B. 1. Properties derived from seismic travel times. 7. Geophys. Res., 92(B9), 8903-8911.

Boulton, G. S. and R. C. A. Hindmarsh. 1987. Sediment deformation beneath glaciers: rheology and geological consequences. F. Geophys. Res. 92(B9), 9059-9082.

Budd, W. F., D. Jenssen and I. N. Smith. 1984. A three-dimensional timedependent model of the West Antarctic ice sheet. Ann. Glaciol., 5, 29-36.

Dowdeswell, J. A. and M. J. Siegert. 1999. Ice-sheet numerical modelling and marine geophysical measurements of glacier-derived sedimentation on the Eurasian Arctic continental margins. Geol. Soc. Am. Bull., 111, 1080-1097.

Fairbanks, R. G. 1989. A 17,000-year glacio-eustatic sea level record: influence of glacial melting rates on the Younger Dryas event and deepocean circulation. Nature, 342(6250), 637-642.

Fjeldskaar, W. 1994. Viscosity and thickness of the asthenosphere detected from the Fennoscandian uplift. Earth Planet. Sci. Lett., 126, 399-410.

Fowler, A. C. and C. Johnson. 1996. Ice-sheet surging and ice-stream formation. Ann. Glaciol., 23, 68-73.

Glen, J.W. 1955. The creep of polycrystalline ice. Proc. R. Soc. London, Ser. A, $228(1175), 519-538$

Hooke, R. LeB. and A. Elverhøi. 1996. Sediment flux from a fjord during glacial periods, Isfjorden, Spitsbergen. Global and Planetary Change, 12(1-4), 237-249.

Huybrechts, P., T. Payne and The EISMINT Intercomparison Group. 1996. The EISMINT benchmarks for testing ice-sheet models. Ann. Glaciol., 23, $1-12$

Jenson, J., P. U. Clark, D. R. MacAyeal, C. Ho and J. C. Vela. 1995. Numerical modelling of advective transport of saturated deforming sediment beneath the Lake Michigan lobe, Laurentide ice sheet. Geomorphology, 14 157-166.

Jenson, J.W., D. R. MacAyeal, P. U. Clark, C. L. Ho and J. C. Vela. 1996. Numerical modeling of subglacial sediment deformation: implications for the behavior of the Lake Michigan lobe, Laurentide ice sheet. f. Geophys. Res., $101(\mathrm{~B} 4), 8717-8728$.
Laberg, J. S. 1996. Late Pleistocene evolution of the submarine fans off the western Barents Sea margin. (Ph.D. thesis, University of Tromsø.)

Lam, J. K.-W. and J. A. Dowdeswell. 1996. An adaptive-grid finite-volume model of glacier-terminus fluctuations. Ann. Glaciol., 23, 86-93.

Lambeck, K. 1995. Constraints on the Late Weichselian ice sheet over the Barents Sea from observations of raised shorelines. Quat. Sci. Rev., 14(1), 1-16.

Le Meur, E. and P. Huybrechts. 1996. A comparison of different ways of dealing with isostasy: examples from modelling the Antarctic ice sheet during the last glacial cycle. Ann. Glaciol., 23, 309-317.

Mahaffy, M.W. 1976. A three-dimensional numerical model of ice sheets: tests on the Barnes Ice Cap, Northwest Territories. 7. Geophys. Res., 81(6), 1059-1066.

Manabe, S. and A. J. Broccoli. 1985. The influence of continental ice sheets on the climate of an ice age. 7. Geophys. Res., 90 (D1), 2167-2190.

Marshall, S. J. and G. K. C. Clarke. 1997. A continuum mixture model of ice stream thermomechanics in the Laurentide ice sheet. 1. Theory. 7. Geophys. Res., 102(B9), 20,599-20,614.

Murray, T. 1990. Deformable glacier beds: measurement and modelling. (Ph.D. thesis, University of Wales, Aberystwyth.)

Oerlemans, J. and G. J. van der Veen. 1984. Ice sheets and climate. Dordrecht, etc., D. Reidel Publishing Co.

Paterson, W. S. B. 1994. The physics of glaciers. Third edition. Oxford, etc., Elsevier.

Pattyn, F. 1996. Numerical modelling of a fast-flowing outlet glacier: experiments with different basal conditions. Ann. Glaciol., 23, 237-246.

Payne, A. J. 1995. Limit cycles in the basal thermal regime of ice sheets. $\mathcal{F}$. Geophys. Res., 100 (B3), 4249-4263.

Pfeffer, W.T. and 7 others. 1997. Numerical modeling of late glacial Laurentide advance of ice across Hudson Strait: insights into terrestrial and marine geology, mass balance, and calving flux. Paleoceanography, 12(1), 97-110.

Shackleton, N. J. 1987. Oxygen isotopes, ice volume and sea level. Quat. Sci. Rev., 6(3-4), 183-190.

Siegert, M. J. and J. A. Dowdeswell. 1995. Numerical modelling of the Late Weichselian Svalbard-Barents Sea ice sheet. Quat. Res., 43(1), 1-13.

Van derVeen, C. J. and I. M. Whillans. 1996. Model experiments on the evolution and stability of ice streams. Ann. Glaciol., 23, 129-137.

Vose, R. S. and 6 others. 1992. The global historical climatology network: long-term monthly temperature, precipitation, sea level pressure, and station pressure data. Oak Ridge, TN. Oak Ridge National Laboratory. (Environmental Sciences Division Publication 3912, CDIAC 53.) 